\title{
Dried brewers' grain as a replacement for soybean meal on nutrient digestibility and rumen parameters of cattle
}

\author{
A. Faccenda ${ }^{1 \#}$, M.A. Zambom², A.S. Avila², T. Fernandes ${ }^{3}$, M.M. Stum², J. Garcias ${ }^{2}$, \\ R.C.R. Tinini ${ }^{2}$ \& A.L.G. Dias ${ }^{4}$ \\ ${ }^{1}$ State University of Maringa, Maringa, Brazil \\ ${ }^{2}$ State University of West of Parana, Marechal Candido Rondon, Brazil \\ ${ }^{3}$ Federal University of Lavras, Lavras, Brazil \\ ${ }^{4}$ University of Alberta, Edmonton, Canada
}

(Received 4 June 2018; Accepted 24 August 2018; First published online 22 December 2018)

\begin{abstract}
Copyright resides with the authors in terms of the Creative Commons Attribution 4.0 South African Licence.
See: http://creativecommons.org/licenses/by/4.0/za

Condition of use: The user may copy, distribute, transmit and adapt the work, but must recognise the authors and the South African Journal of Animal Science.
\end{abstract}

\begin{abstract}
The objective of this study was to determine the effect of replacing soybean meal with dried brewers' grains (DBG) in intake and digestibility of the nutrients and the ruminal parameters of cattle. Four ruminal cannulated Jersey oxen with initial body weight of $662.7 \pm 85.5 \mathrm{~kg}$ were distributed in a $4 \times 4$ Latin square design. The treatments were levels of $0 \%, 33 \%, 66 \%$ and $100 \%$ DBG replacing soybean meal in the diet. Dry matter (DM) and crude protein (CP) intake were not influenced by the treatments. There were linear increases in ether extract (EE), neutral detergent fibre (NDF) and acid detergent fibre (ADF) intakes because of higher levels of these nutrients in diets with DBG. Non-fibre carbohydrate (NFC) and total digestible nutrient (TDN) intake showed a decreasing linear effect. Dry matter and NFC digestibility decreased linearly with rising DBG levels, while EE, CP, NDF and ADF digestibilities were not affected. Ruminal pH was not influenced by DBG levels in the diet. There was a quadratic effect in ammonia nitrogen $\left(\mathrm{NH}_{3}-\mathrm{N}\right)$ concentration in the rumen, with the maximum occurring at a level of $36.7 \%$ DGB. The replacement of soybean meal with DBG in cattle diets did not alter DM intake and ruminal $\mathrm{pH}$, but reduced TDN intake.
\end{abstract}

Keywords: Ammonia nitrogen, by-product, digestibility, intake, $\mathrm{pH}$

\# Corresponding author: andressafaccenda@hotmail.com

\section{Introduction}

The high costs of concentrated ingredients in animal feed and the competition of these with human food have increasingly driven the search for feed alternatives. In addition, the increase in agro-industrial production has generated many by-products that cannot be used directly for human consumption, but can become part of animal diets. This is especially true for ruminants, which, owing to the specific characteristics of their digestive systems, are able to transform these residues into high-quality products such as milk and meat (Pereira et al., 1999).

The current political and social pressure to reduce pollution from industrial activities has caused most countries to adapt to this reality by modifying processes and recycling their by-products. As a result, large companies no longer regard by-products as garbage, but as raw material for other industries (Mussatto et al., 2006). Brewer's grains from the brewing industry have crude protein (CP) ranging from $145 \mathrm{~g} / \mathrm{kg}$ to $374 \mathrm{~g} / \mathrm{kg}$ of dry matter (DM) (Del Ríoet al., 2013; Westendorf et al., 2014), and can be used as a lower cost replacement for soybean meal. However, the peculiar characteristics of this by-product, such as its high neutral detergent fibre (NDF) content, can lead to reduced consumption owing to physical rumen fill (Silva et al., 2010). In addition, its low-degradable protein in the rumen could cause limitations to bacterial growth (Gilavarte et al., 2011) and therefore interfere with the digestion of nutrients by the animal.

Nutrient digestion in turn is a dynamic process that results from the interaction of factors that depend on the animal, diet and animal rumen ecosystem (Pereira et al., 1999). Thus, to determine the effects of dried brewers' grains (DBG) on animal performance, it is critical to introduce this alternative ingredient in the 
production chain of ruminants. The objective of this study was to determine the effects of replacing soybean meal with DBG on intake and digestibility of the nutrients and the ruminal parameters of cattle.

\section{Material and Methods}

The experiment was conducted at State University of West of Parana (Brazil) at the geographic coordinates, $24^{\circ} 31^{\prime} 55^{\prime \prime}$ south and $54^{\circ} 01^{\prime}$ 08' west, and an altitude of $392 \mathrm{~m}$. Research on animals was conducted according to the West Parana State University Committee on Animal Use (Protocol 35/13). Four Jersey oxen with rumen cannulas with initial body weight (BW) of $662.7 \pm 85.5 \mathrm{~kg}$ were used. They were assigned to a $4 \times 4$ Latin square experimental design of four treatments and four experimental periods of 21 days. The first 14 days were for adaptation to the diet and management, and the last seven days were for data collection. The treatments consisted of the replacing of soybean meal with DBG at levels of $0 \%, 33 \%$, $66 \%$ and $100 \%$.

The estimated nutrient composition of DBG, soybean meal, corn grain and silage are presented in Table 1. The total digestible nutrients (TDN) content were calculated using the equation proposed by Kunkle \& Bates (1998) and in vitro organic matter digestibility values previously analysed. The diets were formulated to meet the maintenance requirements of the animals, according to the NRC (1996). The diets were composed of a forage : concentrate ratio of $50: 50$ (Table 2). The soybean meal was gradually replaced with DBG at levels of $0 \%, 33 \%, 66 \%$ and $100 \%$. However, owing to the difference in the CP content between these ingredients, the amount of DBG $(\mathrm{kg})$ used to replace the soybean meal was approximately $3: 1$. TDN in the experimental diets was calculated according to the equation proposed by Sniffen et al. (1992), using the digestibility of the nutrients for each treatment.

Table 1 Nutrient composition ( $\mathrm{g} / \mathrm{kg}$ of dry matter) of the main dietary ingredients in experimental diets

\begin{tabular}{lcccc}
\hline Ingredients & $\begin{array}{c}\text { Dried brewers' } \\
\text { grains }\end{array}$ & Soybean meal & Corn grain & Corn silage \\
\hline Dry matter (g/kg as fed) & 941 & 896 & 889 & 316 \\
Organic matter & 959 & 932 & 982 & 949 \\
Ether extract & 59.2 & 16.2 & 35.9 & 28.8 \\
Crude protein & 217 & 509 & 95.1 & 87.2 \\
Neutral detergent fibre & 662 & 169 & 108 & 474 \\
Acid detergent fibre & 268 & 117 & 50.7 & 290 \\
Non-fibre carbohydrate & 82.7 & 276 & 758 & 381 \\
Total digestible nutrients $^{1}$ & 617 & 778 & 814 & 673 \\
\hline
\end{tabular}

${ }^{1}$ Estimated according to Kunkle \& Bates (1998)

The animals were housed in a covered barn with individual pens. The initial DM offered in each experimental period was $1.8 \mathrm{~kg}$ per $100 \mathrm{~kg}$ of BW. However, during adaptation the refusals were weighed daily and adjusted by $5 \mathrm{~g} / \mathrm{kg}$ of DM offered. The feed was weighed daily and fed twice daily at 06:30 and $16: 30$ in a proportion of $700 \mathrm{~g} / \mathrm{kg}$ and $300 \mathrm{~g} / \mathrm{kg}$, respectively. At the beginning and end of each experimental period the animals were weighed before the morning feeding.

The DM and nutrient intakes were determined as the difference between the amount of feed provided and the refusals between the 15th and 21st days of a period. Samples of feed and refusals of each animal were collected during this period. To determine digestibility, faecal samples were collected directly from the rectum from the 15th to the 20th day, according to this distribution: day 15 (08:00), day 16 (10:00), day 17 (12:00), day 18 (14:00), day 19 (16:00) and day 20 (18:00). Subsequently, samples of feed, refusals and faeces were dried in a forced ventilation air oven $\left(55^{\circ} \mathrm{C}\right.$ for $72 \mathrm{~h}$ ) and ground in a screen with 1-mm sieves. The samples collected during the seven days of the trial were used to compose a representative sample of diets, refusals and faeces per animal per period. Thus, each treatment at the end of the experiment had four diet samples, four refusals samples and four faeces samples. The samples were analysed for DM, ash, CP and ether extract (EE) according to AOAC (1990) methodology, and the NDF and acid detergent fibre (ADF) were determined according to Van Soest et al. (1991). The amounts of organic matter (OM) were calculated 
as the difference between ash content and total DM. Non-fibre carbohydrate (NFC) was calculated according to the equations proposed by Sniffen et al. (1992).

Table 2 Ingredients and nutritional composition ( $\mathrm{g} / \mathrm{kg}$ of dry matter) of the experimental diets

\begin{tabular}{lcccc}
\hline \multirow{2}{*}{ Ingredients } & \multicolumn{4}{c}{ Dried brewers' grain levels (\%) } \\
\cline { 2 - 4 } & $\mathbf{0}$ & $\mathbf{3 3}$ & $\mathbf{6 6}$ & $\mathbf{1 0 0}$ \\
\hline Corn silage & 500 & 500 & 500 & 500 \\
Corn grain & 417 & 398 & 362 & 274 \\
Soybean meal & 68.0 & 58.3 & 41.3 & - \\
Dried brewers' grain & - & 29.1 & 82.6 & 211 \\
Mineral mix ${ }^{1}$ & 9.72 & 9.72 & 9.73 & 9.73 \\
Calcium limestone & 4.37 & 4.37 & 3.89 & 3.89 \\
\hline Nutritional composition & & & & \\
\hline Dry matter (g/kg as fed) & 600 & 603 & 606 \\
Organic matter & 950 & 950 & 950 & 949 \\
Ether extract & 29.1 & 32.7 & 35.7 & 41.5 \\
Crude protein & 120 & 119 & 121 & 122 \\
Neutral detergent fibre & 291 & 317 & 344 & 414 \\
Acid detergent fibre & 170 & 178 & 188 & 216 \\
Non-fibre carbohydrate & 530 & 504 & 478 & 415 \\
Total digestible nutrients ${ }^{2}$ & 652 & 622 & 615 & 629
\end{tabular}

${ }^{1}$ Chemical composition (quantities/kg): Ca: 165 g; P: 73 g; Co: 25 mg; Mg: 15 g; Mn: 1500 mg; Zn: 3000 mg: Se: 10 mg;

I: $40 \mathrm{mg}$; F: $736 \mathrm{mg}$; Fe: $2000 \mathrm{mg}$; Cu: $650 \mathrm{mg}$; Na: $117 \mathrm{~g}$

${ }^{2}$ Estimated according to Sniffen et al. (1992)

Dry matter and nutrient digestibility were estimated as the difference between the amounts consumed and excreted. To estimate daily faecal excretion, insoluble acid detergent fibre (iADF) was used as an internal marker. The iADF was estimated in samples of offered feed, refusals and faeces by an in situ digestibility procedure. The iADF was obtained after 264 hours incubation (Casaliet al., 2008) in filter bags and then analysed for ADF.

To determine ruminal fermentation, ruminal fluid samples were collected from animals before feeding (time 0 ) and 2, 4, 6 and $8 \mathrm{~h}$ after the morning feeding. The liquid was manually collected through the rumen cannula and filtered through cheesecloth. The ruminal $\mathrm{pH}$ was measured immediately after each collection with a digital $\mathrm{pH}$ meter. Samples of $50 \mathrm{~mL}$ ruminal fluid were acidified with $1 \mathrm{~mL}$ sulphuric acid (1:1) and stored at $-20^{\circ} \mathrm{C}$ for subsequent analysis of ammonia nitrogen $\left(\mathrm{NH}_{3}-\mathrm{N}\right)$ concentrations by distillation with $2 \mathrm{~N}$ potassium hydroxide, as described by Fenner (1965).

The data were analysed as a $4 \times 4$ Latin square design using the MIXED procedure of SAS (Statistical Analysis System, version 9.2.). Dried brewers grain levels were considered fixed effect, and period and oxen were considered random effects. The effects of DBG levels were evaluated by regression polynomial testing linear and quadratic models. The variables related to ruminal parameters were analysed with repeated measurements in time. Time and interaction between DBG levels and time were considered fixed effect. Various covariance structures of errors were fitted. The banded structure (UN(1)) was selected based on the lowest Bayesian information criterion. When significant, means were analysed by regression polynomial testing linear and quadratic models. Significance was set at $P<0.05$.

\section{Results and Discussion}

Dry matter intake and OM and CP intakes were not influenced by the treatments $(P>0.05)$ (Table 3 ). The lack of effect may have occurred owing to the low level of DM intake that remained between 1.5 and 1.8 $\mathrm{kg}$ per $100 \mathrm{~kg}$ of BW. Thus, the rumen fill effect caused by diets high in NDF containing brewery residue, as 
reported by Silva et al. (2010), did not occur. Geron et al. (2008) did not observe an effect on DM intake in cattle fed $24 \%$ of wet brewers' grain in the total diet, with an intake level of up to $1.7 \mathrm{~kg}$ per $100 \mathrm{~kg}$ of BW. Crude protein intake was not affected by treatments since the diets had similar protein contents and DM intake was similar between the DBG levels.

Table 3 Daily dry matter and nutrients intake $(\mathrm{kg} / \mathrm{d})$ of cattle fed with various levels of dried brewers' grain replacing soybean meal

\begin{tabular}{|c|c|c|c|c|c|c|c|}
\hline \multirow{2}{*}{ Variables } & \multicolumn{4}{|c|}{ DBG levels (\%) } & \multicolumn{2}{|c|}{ P-value } & \multirow{2}{*}{ SEM } \\
\hline & 0 & 33 & 66 & 100 & Linear & Quadratic & \\
\hline Dry matter intake & 11.76 & 11.73 & 11.63 & 11.17 & 0.12 & 0.36 & 0.32 \\
\hline Organic matter intake & 11.17 & 11.15 & 11.06 & 10.60 & 0.11 & 0.35 & 0.30 \\
\hline Ether extract intake ${ }^{1}$ & 0.35 & 0.38 & 0.41 & 0.47 & $<0.01$ & 0.27 & 0.02 \\
\hline Crude protein intake & 1.41 & 1.41 & 1.40 & 1.36 & 0.21 & 0.38 & 0.03 \\
\hline Neutral detergent fibre intake ${ }^{2}$ & 3.42 & 3.73 & 3.99 & 4.61 & $<0.01$ & 0.05 & 0.09 \\
\hline Acid detergent fibre intake ${ }^{3}$ & 2.00 & 2.09 & 2.16 & 2.38 & 0.01 & 0.34 & 0.09 \\
\hline Non-fibrous carbohydrate intake ${ }^{4}$ & 6.24 & 5.91 & 5.60 & 4.66 & $<0.01$ & 0.08 & 0.21 \\
\hline Total digestible nutrients intake ${ }^{5}$ & 7.66 & 7.19 & 7.09 & 7.02 & 0.04 & 0.32 & 0.26 \\
\hline
\end{tabular}

SEM: standard error of means; DBG: dried brewers' grain

${ }^{1} \hat{Y}=0.3468+0.0012 x\left(R^{2}=0.97\right)$

${ }^{2} \hat{Y}=3.3652+0.0115 \times\left(R^{2}=0.96\right)$

${ }^{3} \hat{Y}=1.9755+0.0036 x\left(R^{2}=0.93\right)$

${ }^{4} \hat{Y}=6.3597-0.0152 \times\left(R^{2}=0.92\right)$

${ }^{5} \hat{Y}=7.5448-0.0061 \times\left(R^{2}=0.82\right)$

There was a linear rise in EE intake, due to increased EE in diets with DBG $(P<0.01)$, which increased from $29.17 \mathrm{~g} / \mathrm{kg}$ of dietary DM with $0 \%$ DBG to $41.5 \mathrm{~g} / \mathrm{kg}$ of dietary DM with $100 \%$ of DBG. Miyazawa et al. (2007) also observed a higher EE intake in lactating cows fed diets with 9\% of DBG in the diet compared with the control treatment. The replacement of soybean meal with DBG also increased linearly the NDF and ADF intakes $(P<0.05)$ owing to the higher concentration of these fractions in diets with DBG.

Non-fibre carbohydrate intake showed a decreasing linear effect with the increased use of DBG $(P<0.01)$. There was a gradual reduction in the NFC concentration of the diets when the soybean meal was replaced by DBG. That reduction occurred due to a decreasing in the corn proportion and also the low NFC content of DBG as a result of the starch removal during malting of the barley (Mussatto et al., 2006). Total digestible nutrient intake had a linear reduction of $6.1 \mathrm{~g}$ per day for each $1 \%$ use of DBG $(P<0.05)$. This effect was due to the lower digestibility of the carbohydrate with increasing DBG instead of soybean meal.

Dry matter and OM digestibility decreased linearly with increasing DBG levels $(P<0.05)$ (Table 4). This result reflects the linear reduction in NFC digestibility $(P<0.05)$. During malting, most of the NFC, mainly starch, is digested by enzymes into simple sugars (Gonzalez-Pereyra et al., 2011). Thus, the remaining NFC of the DBG is more resistant (Tang et al., 2005) to ruminal fermentation affecting the digestibility of this fraction.

The digestibility of EE, CP, NDF and ADF were not changed by the replacement of soybean meal with DBG $(P>0.05)$. Geron et al. (2008) and Sakai et al. (2015) did not observe differences in digestibilities of CP, NDF and ADF when evaluating the inclusion of $24 \%$ fermented brewers' grains in the cattle diet and $29 \%$ DBG in buffalo diet, respectively.

There was no interaction between treatment and time after feeding for ruminal $\mathrm{NH}_{3}-\mathrm{N}$ concentration $(P$ $>0.05)$, but this variable presented a quadratic effect in function of the time $(P<0.01)$ with maximum estimated $\mathrm{NH}_{3}-\mathrm{N}$ concentration at 2:43 hours after feeding. There was a quadratic effect (Figure 1) for the $\mathrm{NH}_{3}-\mathrm{N}$ concentration with the replacement of soybean meal for DBG $(P<0.05)$, wherein the maximum estimated $\mathrm{NH}_{3}-\mathrm{N}$ concentration occurred with the level of $36.7 \%$ of DGB. The higher $\mathrm{NH}_{3}-\mathrm{N}$ concentration, observed at level of $36.7 \%$ of DGB, may maximize microbial protein synthesis, since it is the nitrogen source most used by ruminal bacteria (Wang et al., 2015). However, the use of DBG above this level reduced the 
concentration of ammonia owing to its lower rumen degradability of the protein compared with soybean meal. This fact occurs because the soluble proteins of malt are removed during the malting and brewing process, resulting in a DBG with proteins of low solubility (Steiner et al., 2011).

Table 4 Apparent dry matter and nutrient digestibility ( $\mathrm{g} / \mathrm{kg}$ of dry matter) of cattle diets containing different levels of dried brewers' grain replacing soybean meal

\begin{tabular}{|c|c|c|c|c|c|c|c|}
\hline \multirow{2}{*}{ Variable } & \multicolumn{4}{|c|}{ DBG levels (\%) } & \multicolumn{2}{|c|}{$P$-value } & \multirow{2}{*}{ SEM } \\
\hline & 0 & 33 & 66 & 100 & Linear & Quadratic & \\
\hline Dry matter digestibility ${ }^{1}$ & 722.5 & 685.6 & 664.6 & 663.0 & 0.03 & 0.31 & 22.15 \\
\hline Organic matter digestibility $^{2}$ & 756.5 & 720.2 & 704.3 & 702.1 & 0.03 & 0.27 & 19.67 \\
\hline Ether extract digestibility & 815.7 & 807.8 & 809.7 & 823.9 & 0.76 & 0.57 & 26.04 \\
\hline Crude protein digestibility & 687.2 & 622.7 & 621.9 & 643.5 & 0.16 & 0.06 & 25.57 \\
\hline Neutral detergent fibre digestibility & 548.9 & 544.2 & 551.1 & 578.7 & 0.41 & 0.53 & 33.87 \\
\hline Acid detergent fibre digestibility & 513.6 & 432.4 & 466.5 & 458.3 & 0.33 & 0.23 & 38.78 \\
\hline Non-fibrous carbohydrate digestibility ${ }^{3}$ & 845.0 & 807.7 & 785.2 & 784.6 & 0.01 & 0.15 & 15.91 \\
\hline
\end{tabular}

SEM: standard error of means; DBG: dried brewers' grain

${ }^{1} \hat{Y}=713.6365-0.5976 x\left(R^{2}=0.86\right)$

${ }^{2} \hat{Y}=747.4185-0.5360 \times\left(R^{2}=0.84\right)$

${ }^{3} \hat{Y}=835.9432-0.6099 x\left(R^{2}=0.85\right)$

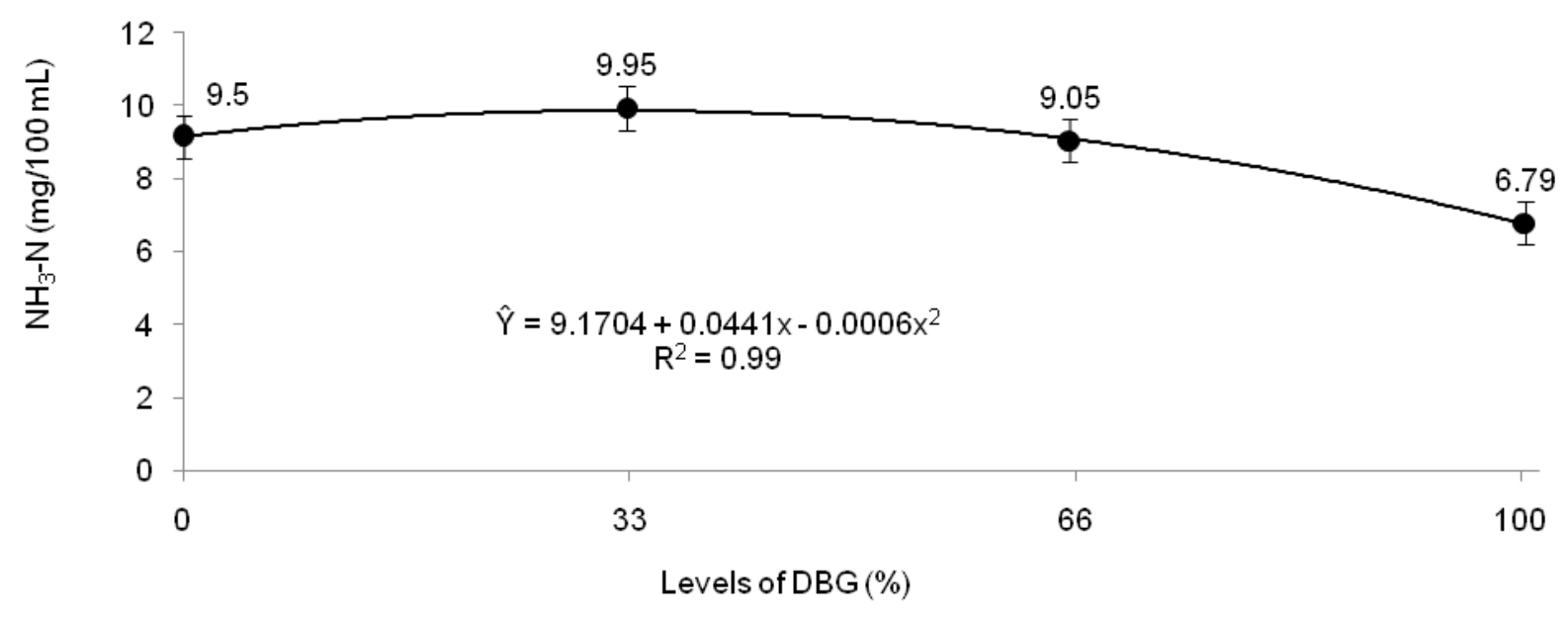

Figure 1 Ruminal ammonia nitrogen concentration of cattle fed levels of dried brewers' grain (DBG) as a replacement for soybean meal

The ruminal $\mathrm{pH}$ in cattle showed no interaction between treatment and evaluation times and was not influenced by DBG levels in the diet $(P>0.05)$. Ruminal $\mathrm{pH}$ showed quadratic effect in function of the time after feeding $(P<0.01)$ and the minimum estimated $\mathrm{pH}$ value occurred at 4.51 hours after feeding. Regardless of the treatment and time after feeding, the $\mathrm{pH}$ remained above 5.8, which is considered by Yang \& Beauchemin (2007) to be the minimum pH value at which there is not reduced fibre digestibility.

\section{Conclusion}

The replacement of soybean meal with DBG in cattle diets did not alter DM intake and ruminal $\mathrm{pH}$, but reduced TDN intake owing to the lower NFC digestibility. The level of $36.7 \%$ of DBG provided the highest ruminal $\mathrm{NH}_{3}-\mathrm{N}$ concentration that can maximize microbial protein synthesis. 


\section{Acknowledgments}

The authors would like to thank Coordenação de Aperfeiçoamento de Pessoal de Nível Superior (CAPES grant PNPD 2891/2010) for their financial support.

\section{Authors' Contributions}

AF, MAZ and ALGD were in charge of project design and writing of the manuscript. AF, ASA, TF, MMS, JG, and RCRT were in charge of project implementation. All co-authors participated in results, statistics and interpretation of the study.

\section{Conflict of Interest Declaration}

The authors declare no conflict of interest.

\section{References}

AOAC, 1990. Official methods of analysis. (16th ed.). Association of Official Analytical Chemists, Inc. Arlington, Virginia, USA.

Casali, A.O., Detmann, E., Valadares Filho, S.C., Pereira, J.C., Henriques, L.T., Freitas, S.G. \& Paulino, M.F., 2008. Influence of incubation time and particles size on indigestible compounds contents in cattle feeds and feces obtained by in situ procedures. Braz. J. Anim. Sci. 37, 335-342(in Portuguese, English abstract).

Del Río, J.C., Prinsen, P. \& Gutiérrez, A., 2013. Chemical composition of lipids in brewer's spent grain: A promising source of valuable phytochemicals. J. Cereal Sci. 58, 248-254.

Fenner, H., 1965. Method for determining total volatile bases in rumen fluid by steam distillation. J. Dairy Sci. 48, 249-251.

Geron, L.J.V., Zeoula, L.M., Erkel, J.A., Prado, I.N., Jonker, R.C. \& Guimarães, K.C., 2008. Digestibility coefficient and ruminal characteristics of cattle fed ration containing brewer grains. Braz. J. Anim. Sci. 37, 1685-1695. (in Portuguese, English abstract).

Gilaverte, S., Susin, I., Pires, A.V., Ferreira, E.M., Mendes, C.Q., Gentil, R.S., Biehl, M.V. \& Rodrigues, G.H., 2011. Diet digestibility, ruminal parameters and performance of Santa Ines sheep fed dried citrus pulp and wet brewer grain. Braz. J. Anim. Sci. 40, 639-647. (in Portuguese, English abstract).

Gonzalez-Pereyra, M.L., Rosa, C.A.R., Dalcero, A.M. \& Cavaglieri, L.R., 2011. Mycobiota and mycotoxins in malted barley and brewer's spent grain from Argentinean breweries. Lett. Appl. Microbiol. 53, 649-655.

Kunkle, W.E. \& Bates, D.B., 1998. Evaluating feed purchasing options: energy, protein, and mineral supplements. In: Proceedings of the Florida Beef Cattle Short Course. University of Florida, Gainesville, Florida, USA. pp. 59-70.

Miyazawa, K., Sultana, H., Hirata, T., Kanda, S. \& Itabashi, H., 2007. Effect of brewer's grain on rumen fermentation, milk production and milk composition in lactating dairy cows. Anim. Sci. J. 78, 519-526.

Mussato, S.I., Dragone, G. \& Roberto, C., 2006. Brewer's spent grain: generation, characteristics and potential applications. J. Cereal Sci. 43, 1-14.

NRC, 1996. Nutrient Requirements of Beef Cattle. 7th edition. National Academy Press, Washington, DC, USA.

Pereira, J.C., Gozález, J., Oliveira, R.L. \& Queiroz, A.C., 1999. Ruminal degradation kinetics of brewers grain submitted to different dehydration temperatures. Braz. J. Anim. Sci. 28, 1125-1132. (in Portuguese, English abstract).

Sakai, T., Devkota, N.R., Oishi, K., Hirooka, H. \& Kumagai, H., 2015. Evaluation of total mixed ration silage with brewersgrains for dairy buffalo in Tarai, Nepal. Anim. Sci. J. 86, 884-890.

Silva, V.B., Fonseca, C.E.M., Morenz, M.J.F., Peixoto, E.L.T., Moura, E.S. \& Carvalho, I.N.O., 2010. Wet brewer grains on goat feeding. Braz. J. Anim. Sci. 39, 1595-1599. (in Portuguese, English abstract).

Sniffen, C.J., O'Connor, J.D., Van-Soest, P.J., Fox, D.G. \& Russell, J.B., 1992. A net carbohydrate and protein system for evaluating cattle diets: II. Carbohydrate and protein availability. J. Anim. Sci. 70, 3562-3577.

Steiner, E., Gastl, M. \& Becker, T., 2011. Protein changes during malting and brewing with focus on haze and foam formation: A review. Eur. Food Res. Technol. 232, 191-204.

Tang, Z., Cenkowski, S. \& Izydorczyk, M., 2005. Thin-layer drying of spent grains in superheated steam. J. Food Eng. 67, 457-465.

Van Soest, P.J., Robertson, J.B. \& Lewis, B.A., 1991. Carbohydrate methodology, metabolism, nutritional implications in dairy cattle. J. Dairy Sci. 74, 3583-3597.

Wang, P., Tan, Z., Guan, L., Tang, S., Zhou, C., Han, X., Kang, J. \& He, Z., 2015. Ammonia and amino acids modulate enzymes associated with ammonia assimilation pathway by ruminal microbiota in vitro. Livest. Sci. 178, 130-139.

Westendorf, M.L., Wohlt, J.E., Sniffen, C.J. \& Ward, R.T., 2014. Nutrient content of brewers grains produced at a commercial brewery: Variation in protein/ nitrogen, fiber, carbohydrate, fat, and minerals. Professional Animal Scientist 30, 400-406.

Yang, W.Z. \& Beauchemin, K.A., 2007. Altering physically effective fiber intake through forage proportion and particle length: chewing and ruminal pH. J. Dairy Sci. 90, 2826-2838. 